СНЕЖКОВА Ирина Анатольевна - кандидат исторических наук, старший научный сотрудник Института этнологии и антропологии им. Н.Н. Миклухо-Маклая, РАН(119334, Россия, г. Москва, Ленинский пр-кт, 32A; snezhkova@ mail.ru)

КАЛАЧЕВА Ирина Ивановна - доктор исторических наук, профессор кафедры социальных коммуникаций факультета философии и социальных наук Белорусского государственного университета (Беларусь, г. Минск, пр-кт Независимости, 4; irakalachova@таil.ru)

ШАЛЫГИНА Наталья Валентиновна - кандидат исторических наук, старший научный сотрудник Института этнологии и антропологии им. Н.Н. Миклухо-Маклая, РАН(119334, Россия, г. Москва, Ленинский $n$-кт, 32A; etgender@mail.ru)

ГРОМОВ Дмитрий Вячеславович - доктор исторических наук, ведущий научный сотрудник Института этнологии и антропологии им. Н.Н. Миклухо-Маклая, РАН (119334, Россия, г. Москва, Ленинский np-кт, 32A; gromovdv@mail.ru)

\title{
ОБРАЗЫ РОССИИ И БЕЛОРУССИИ В ПРЕДСТАВЛЕНИЯХ МОЛОДЕЖИ ДВУХ СТРАН
}

\begin{abstract}
Аннотация. В 2018-2019 гг. в ряде университетов Москвы и Минска было проведено социологическое и этнопсихологическое исследование, изучающее образ России и Белоруссии с точки зрения студентов двух стран. В условиях информационного и санкционного давления на Россию и Белоруссию важно было изучить, каким образом российская и белорусская молодежь реагирует на сложившиеся условия, каким ей представляется образ России и Белоруссии, какие этнические характеристики молодежь приписывает друг другу, в каких случаях молодежь испытывает чувство гордости и патриотизма за свою страну. Исследовались также особенности этнической идентичности молодежи двух стран. Результаты исследования показали, что, несмотря на сложную этнополитическую обстановку в мире, молодежь России и Белоруссии демонстрирует позитивное отношение к собственному народу и к народу-соседу. Ключевые слова: образ России и Белоруссии, этнические стереотипы русских и белорусов, чувство гордости и патриотизма, этническая идентичность россиян и белорусов
\end{abstract}

И сследование, изучающее образ России и Белоруссии с точки зрения студентов двух стран, проводилось в 2018-2019 гг. в Москве и Минске. Всего были опрошены 400 чел. В Москве опрашивались студенты Московского государственного технического университета им. Н.Э. Баумана (МГТУ им. Н.Э. Баумана), Института журналистики и литературного творчества (ИЖЛТ), Российского государственного гуманитарного университета (РГГУ), Института социальной инженерии Российского гуманитарного университета им. А.Н. Косыгина (ИСИ РГУ); Московского государственного университета технологий и управления им. К.Г. Разумовского (ПКУ). В Минске исследование проводилось среди студентов Белорусского государственного университета.

Главная цель исследования заключалась в сопоставлении взглядов представителей российской и белорусской молодежи по ряду сегодняшних межгосударственных отношений. Для достижения цели решались такие исследовательские задачи, как изучение особенностей национальной идентичности, определение содержания авто- и гетеростереотипов российской и белоруской молодежи, источников зарождения и развития чувства патриотизма и гордости за свою страну, роли средств массовой информации в создании образа России и Белоруссии.

Основным методом исследования был социологический опрос. Для изучения этнической идентичности применялся модифицированный тест М. Куна и Т. Макпартленда «Кто я?». Этническая толерантность/интолерантность исследовалась с помощью изучения положительной/отрицательной направ- 
ленности этнических авто- и гетеростереотипов по методике Д. Катца и К. Брели; при характеристике образа стран использовался ассоциативный метод.

Этническая идентичность в представлениях российской и белорусской молодежи. Этническая идентичность - это ядро этнического самосознания. При спокойных межнациональных отношениях или в моноэтничной среде этническая идентичность в сознании людей чаще всего не актуализирована, однако в случае переломных исторических моментов или межэтнических конфликтов она может приобретать большую значимость. Известно, что наиболее оптимальна та этническая идентичность, которая позитивна по отношению к себе и другим этническим группам. Отклонения от нормы могут происходить по типу гиперэтничности (этнонационализм) и этнической индифферентности (этнонигилизм) [Солдатова 1998: 106-107]. С помощью вопроса: «Кто я?» - мы изучали, как часто встречается этническая идентичность («я - русский», «я белорус») и другие виды идентичности. Результаты опроса молодежи двух стран показали доминирование объективных общечеловеческих характеристик, связанных с социальным статусом, семейными ролями, полом, возрастом, родом занятий, т.е. с группами, к которым нельзя не принадлежать в обществе, наднациональными. Национальная принадлежность у русских встречалась редко $(18 \%)$, у белорусов несколько чаще $(20 \%)$ и занимала в иерархии ценностей последние места.

Нам важно было узнать, какие чувства вызывает этническая принадлежность у русских и белорусов (см. табл. 1).

Таблица 1

Чувства, связанные с этнической принадлежностью, в \% от числа опрошенных

\begin{tabular}{|l|c|c|}
\hline $\begin{array}{c}\text { Чувства, вызываемые принадлежностью } \\
\text { к своему народу }\end{array}$ & Русские студенты & Белорусские студенты \\
\hline $\begin{array}{l}\text { Положительные (гордость, } \\
\text { спокойная уверенность) }\end{array}$ & 84 & 83 \\
\hline Никаких чувств & 12 & 7 \\
\hline Обида, униженность & 4 & 2 \\
\hline Другое & 10 & 8 \\
\hline
\end{tabular}

Мы видим, что в целом у двух народов преобладает положительная национальная идентичность.

Автостереотипы и гетеростереотипы российской и белорусской молодежи. Резкое преобладание положительных автостереотипов «мы» и отрицательных гетеростереотипов «они» говорит о конфликтности или соперничестве между этносами. Наоборот, преобладание негативного оценочного компонента служит показателем нарушения позитивной идентичности членов группы и размытого чувства «мы». Самый лучший вариант, свидетельствующий об устойчивости этнической идентичности, - это совпадение автостереотипов и гетеростереотипов [Стефаненко 1999: 246].

Исследование этнических стереотипов российских и белорусских студентов о себе и о представителях другого народа показало наличие спокойных межнациональных отношений. Автостереотипы русских и белорусов отличались позитивностью, гетеростереотипы также носили преимущественно позитивный характер с небольшой долей критичности, как и положено при характеристике другого. Наиболее повторяющиеся стереотипы русских и белорусов приведены в табл. 2. 
Таблица 2

Авто- и гетеростереотипы российских и белорусских студентов

\begin{tabular}{|l|l|l|l|}
\hline $\begin{array}{c}\text { Автостереотипы } \\
\text { русских о себе }\end{array}$ & $\begin{array}{c}\text { Автостереотипы } \\
\text { белорусов о себе }\end{array}$ & $\begin{array}{c}\text { Гетеростереотипы } \\
\text { русских о белорусах }\end{array}$ & $\begin{array}{c}\text { Гетеростереотипы } \\
\text { белорусов о русских }\end{array}$ \\
\hline Сильные & Спокойные & Добрые & Активные \\
Смелые & Мирные & Честные & Смелые \\
Добрые & Дружелюбные & Гостеприимные & Гордые \\
Работящие & Добрые & Открытые & Честные \\
Честные & Гостеприимные & Терпеливые & Добрые \\
Щедрые & Скрытные & Хозяйственные & Искренние \\
Строгие & Терпеливые & Чистоплотные & Имперские \\
Суровые & Простые & Патриотичные & Агрессивные \\
\hline
\end{tabular}

Образы России и Белоруссии. Для выявления содержательного наполнения образа страны нами был использован метод свободных ассоциаций: респонденты должны были вписать в бланк анкеты ассоциации, связанные с Россией и Белоруссией.

Исследование показало, что большинство респондентов выделяют природногеографические, исторические, культурные, политические и экономические характеристики России и Белоруссии. Молодежь продемонстрировала знание собственной и соседней стран и позитивное к ним отношение [Муха 2013: 81].

Российские студенты о России:

1) природные характеристики: березы, тайга, Байкал, Сибирь, медведь;

2) культурные характеристики: Кремль, Золотое кольцо, промыслы (гжель, хохлома), писатели, художники;

3) исторические характеристики: победа над Наполеоном, победа в Великой Отечественной войне, СССР, Российская Федерация, полеты в космос;

4) политические характеристики: флаг, гимн, Романовы, Путин, независимая политика государства;

5) экономические характеристики: нефть, газ, космическая отрасль, нестабильность.

Российские студенты о Белоруссии:

1) природные характеристики: Беловежская пуща, реки, поля, зубры, картошка;

2) культурные характеристики: «Славянский базар», Якуб Колас, группа Би-2;

3) исторические характеристики: Великая Отечественная война, партизаны, Брестская крепость, патриотизм;

4) политические характеристики: Лукашенко, батька, авторитаризм, порядок;

5) экономические характеристики: сельское хозяйство, фермы, Белаз.

Белорусские студенты о Белоруссии:

1) природные характеристики: Беловежская пуща, леса, озера, реки, аисты, зубры;

2) культурные характеристики: замки, ремесла, чистота, художники;

3) политические характеристики: батька, Лукашенко, порядок;

4) экономические характеристики: развитое сельское хозяйство, фермы, Белаз, инфляция.

Белорусские студенты о России:

1) природные характеристики: березы, медведи, природное разнообразие;

2) культурные характеристики: Пушкин, Лермонтов, Кремль;

3) политические характеристики: сильное вооружение, Путин, империя; 
4) экономические характеристики: нефть, газ, нестабильность.

Геополитические интересы России и Белоруссии. В настоящее время Россия и Белоруссия декларируют идею построения союзного государства и нахождения в единых торгово-экономических союзах. Нам было интересно узнать, что по этому поводу думает студенческая молодежь (см. табл. 3).

Таблица 3

Представление русской и белорусской молодежи о наиболее целесообразной для России и Белоруссии форме государственности, в \% от числа опрошенных

\begin{tabular}{|l|c|c|}
\hline \multicolumn{1}{|c|}{ Государственное устройство } & Русские о России & Белорусы о Белоруссии \\
\hline Независимое государство & 70 & 73 \\
\hline Союзное государство & 25 & 14 \\
\hline Евросоюз & 5 & 13 \\
\hline
\end{tabular}

Мы видим, что молодежь двух стран предпочитает находиться в составе собственного независимого государства. На 2-м месте стоит нахождение в составе Союзного государства. В составе Евросоюза готовы находиться $13 \%$ белорусов и $5 \%$ россиян.

Нам было интересно узнать, как оценивает российская и белорусская молодежь отношения друг с другом, Европейским союзом и США. Российская молодежь $(65 \%)$ и белорусская $(74 \%)$ позиционируют отношения россиян и белорусов на межгосударственном уровне как дружественные. Большинство российской $(62 \%)$ и белорусской молодежи $(72 \%)$ характеризовали отношения с Евросоюзом как нейтральные. Отношения с США больше половины российских $(78 \%)$ и белорусских (65\%) респондентов расценивает как недружественные.

Представления российской и белорусской молодежси о патриотизме. В настоящее время патриотические установки носят достаточно выраженный характер в обеих странах. На вопрос: «Что такое патриотизм?»- и русские, и белорусские студенты отвечали, что это прежде всего «любовь к своей стране», «гордость за нее», «вера в государство». Однако расширенный вариант ответа на этот вопрос показал, что представление о патриотизме у российских и белорусских студентов имеет различное наполнение.

Так, чувство патриотизма для русских складывается из «успехов страны на международной арене», «достижений в области спорта и культуры». При этом российские студенты особо отмечают, что их патриотизм однозначно опирается на такой фундамент, как «независимая политика страны на международной арене и укрепление суверенитета России в современном мире» $(85 \%)$. Практически все российские студенты «гордятся победой СССР в Великой Отечественной войне» и однозначно соотносят этот исторический факт с гордостью за Россию.

Белорусские студенты отвечают, что гордость за страну они ощущают в связи с «ее мирной и взвешенной политикой», «согласием народа и его руководства», «наличием порядка в стране» $(76 \%)$.

На вопрос: «Увеличилось ли чувство патриотизма в стране?» - и российские, и белорусские студенты отвечают положительно, что, как мы полагаем, может быть не в последнюю очередь связано с мобилизационным моментом, возникшим на фоне усиления международных санкций как в отношении России, так и (в определенной степени) в отношении Белоруссии.

Влияние СМИ на представления россиян и белорусов друг о друге. Источники формирования образа России и Белоруссии - это, прежде всего, средства мас- 
совой информации. Молодежь в первую очередь черпает информацию через Интернет и социальные сети, в меньшей мере - через телевидение и в малой степени - через газеты и журналы. В настоящее время в СМИ развернута настоящая информационная война, прежде всего против России [Снежкова 2016].

Практически все спорные и нераскрытые прецеденты на мировой арене приписываются «агрессивной России»: «аннексия» Крыма, война в Донбассе, гибель малазийского самолета М-17, дело Скрипалей, события в Керченском проливе и т.д. Белоруссию западные СМИ описывают как «страну, находящуюся под управлением президента-диктатора, не допускающего свободы слова и тесно сотрудничающую с “агрессивной” Россией». Несмотря на обвинения коллективного Запада, Россия и Белоруссия в собственном медийном пространстве существуют довольно позитивно. Лейтмотив основных публикаций: «Россия - большая страна, способная защитить в военном отношении и поддержать экономически Белоруссию», «Белоруссия - надежный политический и экономический партнер России». Безусловно, в СМИ поднимаются и некоторые спорные вопросы: торг руководства двух стран из-за цены на энергоносители, провоз санкционных продуктов в Россию через границу Белоруссии и др. Однако спорные вопросы решаются, а новости друг о друге отличаются в основном спокойным позитивом и доброжелательностью.

Выводы. Предварительные результаты исследования показали, что чувство этнической идентичности у русских и белорусов отличается стабильностью, межэтнические отношения - спокойные. Авто- и гетеростереотипы в целом свидетельствуют о позитивном восприятии молодежью двух стран друг друга. В геополитическом отношении каждая из стран хотела бы сохранять независимость. Чувство патриотизма у русских и белорусов выражено ярко, но не переходит в стадию национализма. В целом, можно сказать, что молодежь двух стран позитивно воспринимает друг друга и видит совместное будущее во взаимодействии двух стран.

Статья выполнена в рамках проекта РФФИ № 18-59-0000-5.

\section{Список литературы}

Муха В.Н. 2013. Образ страны и образ народа: россияне о Беларуси и белорусах. - Теория и практика общественного развития. № 9. С. 80-82.

Снежкова И.А. 2016. Отражение гибридной войны в электронных ресурсах Украины и России. - Вестник антропологии. № 4(36). С. 174-185.

Солдатова Г.У. 1998. Психология межэтнической напряженности. М.: Смысл. 389 c.

Стефаненко Т.Г. 1999. Этнопсихология. М.: Институтт психологии РАН; Академический проект. 320 с. 
SNEZHKOVA Irina Anatol'evna, Cand.Sci. (Hist.), Senior Researcher of the Institute of Anthropology and Ethnography, RAS (32A Leninsky Ave, Moscow, Russia, 119334; snezhkova @ mail.ru)

KALACHYOVA Irina Ivanovna, Dr.Sci. (Hist.), Professor of the Chair of Social Communications, Faculty of Philosophy and Social Sciences, Belarusian State University (4 Nezavisimosti Ave, Minsk, Belarus; irakalachova@mail.ru)

SHALYGINA Natalya Valentinovna, Cand.Sci. (Hist.), Senior Researcher of the Institute of Anthropology and Ethnography, RAS(32A Leninsky Ave, Moscow, Russia, 119334; etgender@mail.ru)

GROMOV Dmitriy Vyacheslavovich, Dr.Sci. (Hist.), Leading Researcher of the Institute of Anthropology and Ethnography, RAS (32A Leninsky Ave, Moscow, Russia, 119334; gromovdv@mail.ru)

\title{
THE IMAGES OF RUSSIA AND BELARUS IN THE VIEWS OF THE YOUTH OF THE TWO COUNTRIES
}

\begin{abstract}
In 2018-2019, a number of universities in Moscow and Minsk conducted a sociological and ethno-psychological study of the image of Russia and Belarus from the point of view of students from the two countries. In terms of information and sanctions pressure on Russia and Belarus, it was important to study how Russian and Belarusian youth react to the current conditions. How do they percept the image of Russia and Belarus? What are the ethnic characteristics the youth of the both countries ascribe to each other? When young people feel a sense of pride and patriotism for their country? The authors also study features of the ethnic identity of the youth of the two countries. The results of the study showed that despite the difficult ethno-political situation in the world, the youth of Russia and Belarus demonstrate positive attitude both to their own nation and to the neighbor people.

Keywords: image of Russia and Belarus, ethnic stereotypes of Russians and Belarusians, pride, patriotism, ethnic identity of Russians and Belarusians
\end{abstract}

ЩЕРБАКОВА Лидия Ильинична - доктор социологических наук, профессор кафедры социологии и психологии Южно-Российского государственного политехнического университета (НПИ) им. М.И. Платова (346428, Россия, Ростовская обл., г. Новочеркасск, ул. Просвещения, 132; lidianpi@mail.ru)

ФИЛОНЕНКО Виктор Иванович - доктор социологических наук, профессор Института философии и социально-политических наук, директор Центра социально-политических исследований Южного федерального университета (344065, Россия, г. Ростов-на-Дону, пер. Днепровский, 116, кopn. 3; vfilonenko@sfedu.ru)

\section{ДЕЯТЕЛЬНЫЙ ПАТРИОТИЗМ КАК ФАКТОР ТВОРЧЕСКОГО РАЗВИТИЯ РОССИЙСКОЙ МОЛОДЕЖИ В УСЛОВИЯХ ИЗМЕНЯЮЩЕЙСЯ СОЦИАЛЬНОЙ РЕАЛЬНОСТИ: ПРОТИВОРЕЧИЯ ФОРМИРОВАНИЯ}

Аннотация. В статье раскрывается значение деятельного патриотизма как связующего звена моральнонравственного облика человека. Авторы описывают признаки социальной неопределенности как фактора формирования гражданско-патриотических качеств молодежи, раскрывают роль культуры, исторической памяти, традиций в формировании гражданской идентичности. В статье обозначена объективная потребность в восстановлении функции образования в гражданско-патриотическом воспитании и в повышении статуса учителя как символа нравственности и патриотизма.

Ключевые слова: патриотизм, деятельный патриотизм, гражданская идентичность, социальная реальность, мотивационно-смысловая сфера, солидаристские практики 